\title{
PR Controlled Hybrid Cuk Converter Inverter fed Induction Heating System
}

\author{
S.Dinakar Raj ${ }^{\# 1}$, G. Angeline Ezhilarasi ${ }^{* 2}$ \\ ${ }^{\#}$ SELECT, VIT University, Chennai, India \\ * SELECT, VIT University, Chennai, India \\ 1'rajdina@gmail.com, ${ }^{2}$ angelineezhilarasi.g@vit.ac.in
}

Abstract- Cuk-converter is utilized to step-up voltage with reduced ripple in the output. Cuk-converter is a better interface between D.C. source and resonant inverter. This research proposes Hybrid Cuk Converter Inverter (HCCI) for induction heating. This paper works with modelling and simulation of closed-loop controlled HCCI system. The response of the battery system is stepped-up using a Cuk converter. The output of the Cuk converter is inverted \& applied to a DC load. Closed loop PI and PR controlled HCCI systems are simulated and their time responses are compared. The hardware of HCCI is engineered \& tested. The results indicate that PR controlled Cuk-converter system has enhanced timedomain response.

Keyword - HCCI- Hybrid Cuk Converter Inverter, IH- Induction Heating, THD- Total Harmonic Distortion. EMI- Electromagnetic Interference, PR- Resonance controller

\section{INTRODUCTION}

Hybrid-converter with boost-converter and resonant-inverter is presented in [1].Synchronous-control of boost-inverter for stand-alone nano-grid is proposed in [2]. Induction-heating is one of the huge uses of power-amplifiers.

Class-EF amplifier with high switching frequency is depicted [3]. Reduction of harmonic-content in CFAS is given in [4]. Theory of R_F-Amplifier is given in [5]. Experimental-Results of CEIH is given in [6]. Current-mirroring of CDAS is given in [7]. Phase-shifted PWMI for IH is presented in [8]. IH using spiral inductors is depicted in [9]. Nature of CFAS and CIFAS is described in [10].

The collected works discussed above does not incorporate with PR controlled HCCI based induction heating system. This work proposes PR controller for enhancement of dynamic response of HCCI system.

This paper encloses the subsequent sections; section-2 deals with IH system. Details of existing system and recommended system are appeared in section II. Analysis of HCCI is appeared in section-3. The simulationresults obtained are displayed in section -4 . Hardware results are displayed in section -5 . The work is concluded in section-6.

\section{IH SYSTEM}

Prevailing Class-D amplifier fed IH system is shown in Fig. 1.

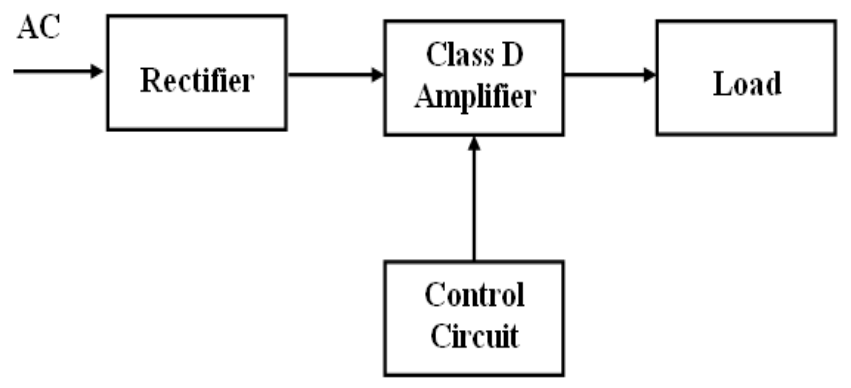

Fig. 1. Prevailing Class-D amplifier fed IH system

The HCCI based IH system is presented in Fig. 2. The response of the Cuk converter is transformed into high-frequency AC using resonance inverter. Actual load voltage is matched with the fixed value of set-voltage and the difference is given to PR Controlled Cuk converter. The output of error detector is stipulated to pulse generator. The output voltage is regulated using PR. 


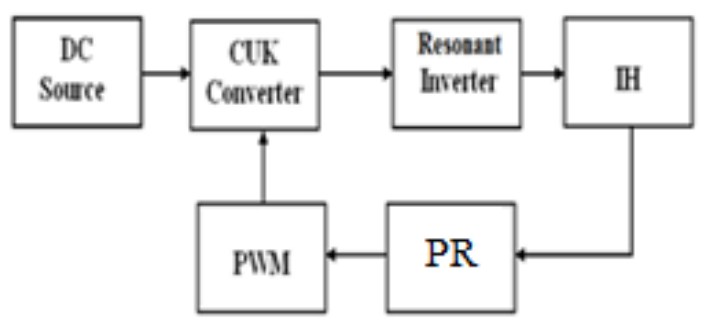

Fig. 2. Proposed HCCI based IH system using PR Controller

\section{ANALYSIS OF HCCI}

The analysis of HCCI is appeared in this section

The current across the load is

$\mathrm{i}=\mathrm{K}$ e- $\mathrm{ftSinwt}$

Output of PI controller is

$\mathrm{V}_{\mathrm{PI}}=\mathrm{K}_{\mathrm{p}} \mathrm{e}+\mathrm{K}_{\mathrm{I}} \int \mathrm{edt}$

The output of PR in $\mathrm{S}$ domain in as follows

$\mathrm{V}_{0(\mathrm{~s})}=\mathrm{K}_{\mathrm{P}} \mathrm{E}_{(\mathrm{S})}+\mathrm{K}_{\mathrm{I}} \mathrm{E}_{(\mathrm{S})} / \mathrm{S}^{\mathrm{m}}+\mathrm{K}_{\mathrm{D}} \mathrm{S}^{\mathrm{n}} \mathrm{E}_{(\mathrm{S})}$

The power-loss in the Induction Coil is

$\mathrm{P}=\mathrm{I}^{2} \mathrm{R}+\mathrm{K}_{1} \mathrm{~B}^{2} \mathrm{f}^{2} \mathrm{t}^{2}+\mathrm{K}_{2} \mathrm{~B}^{1.7} \mathrm{~F}_{\mathrm{V}}$

\section{SIMULATION RESULTS}

Open-loop HCCI system with variations in the input is appeared in Fig. 3.1. A step amendment in DCinput voltage is pertained. The DC voltage is fed to HCCI-System is shown in Fig. 3.2. The current response of HCCI is shown in Fig. 3.3. The voltage and power response of HCCI system as shown in Fig. 3.4 and 3.5.The increase in output parameters is due to the rise in input voltage.

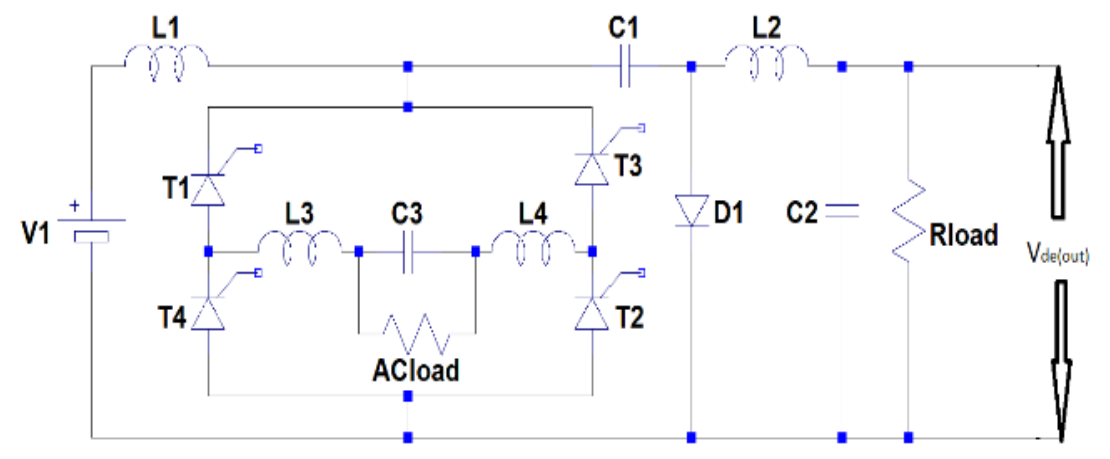

Fig. 3.1. Open-loop HCCI system with variation in input

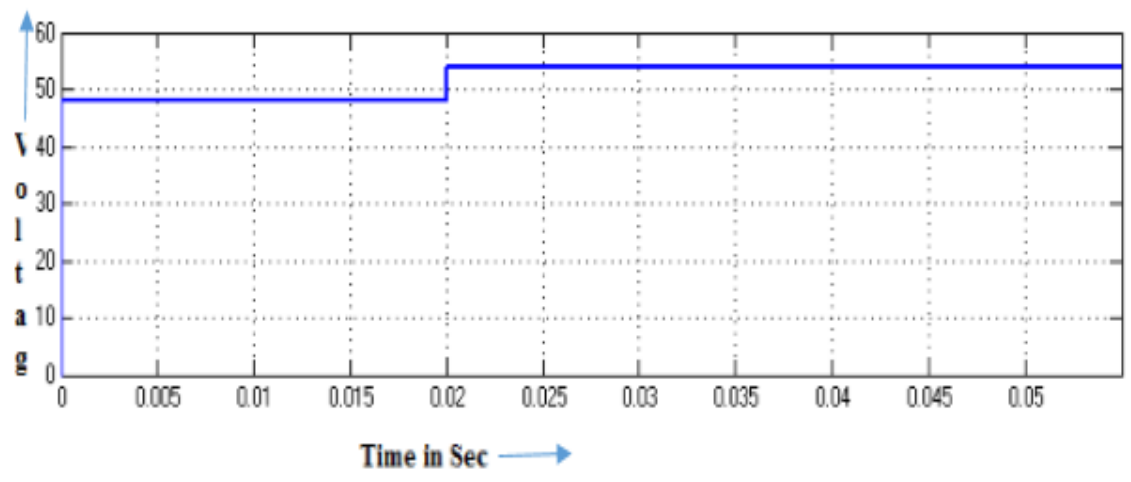

Fig. 3.2. Voltage fed to HCCIS 


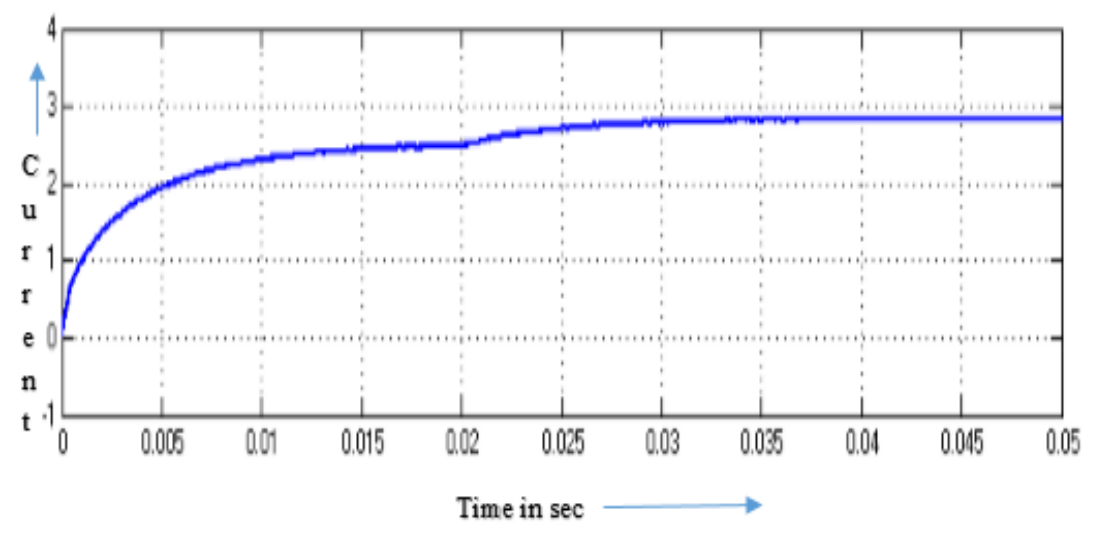

Fig. 3.3. Current response of HCCIS

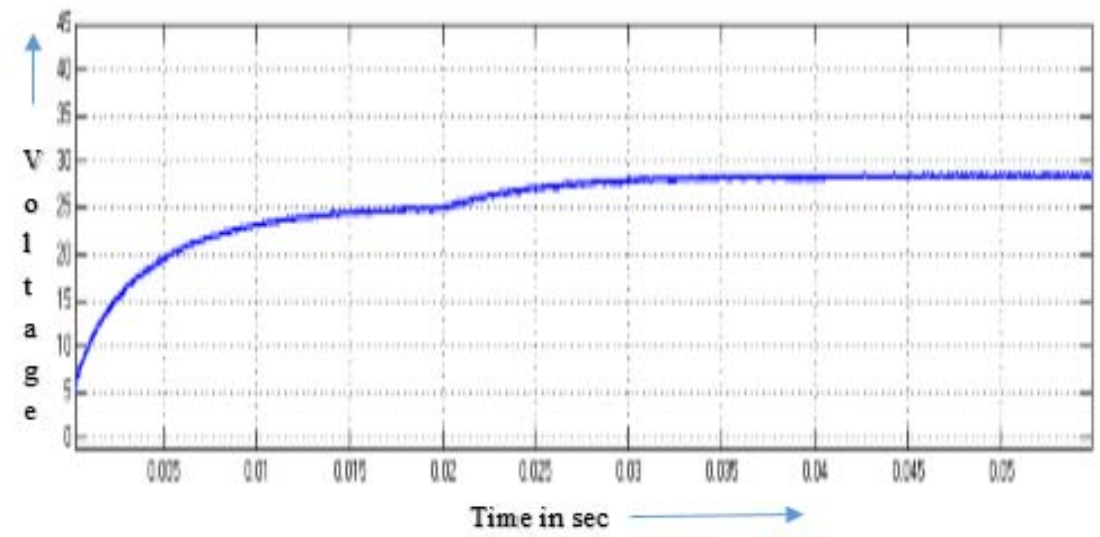

Fig. 3.4.Voltage response of HCCIS

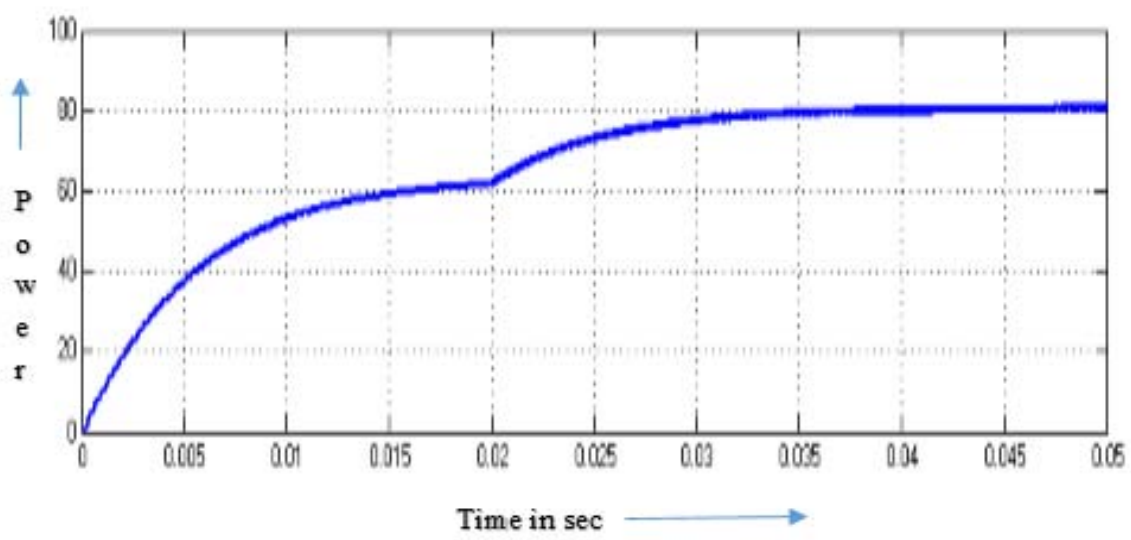

Fig. 3.5. Power response of HCCIS

Closed loop HCCI system with proportional-integral controller is shown in Fig. 4.1. The output pulses from the comparator drives the shunt MOSFET of CUK-converter. The DC voltage fed to HCCI-System is shown in Fig. 4.2. The current response of HCCI is shown in Fig. 4.3. The Voltage and Power response of HCCI system are shown in Fig. 4.4 and 4.5. 


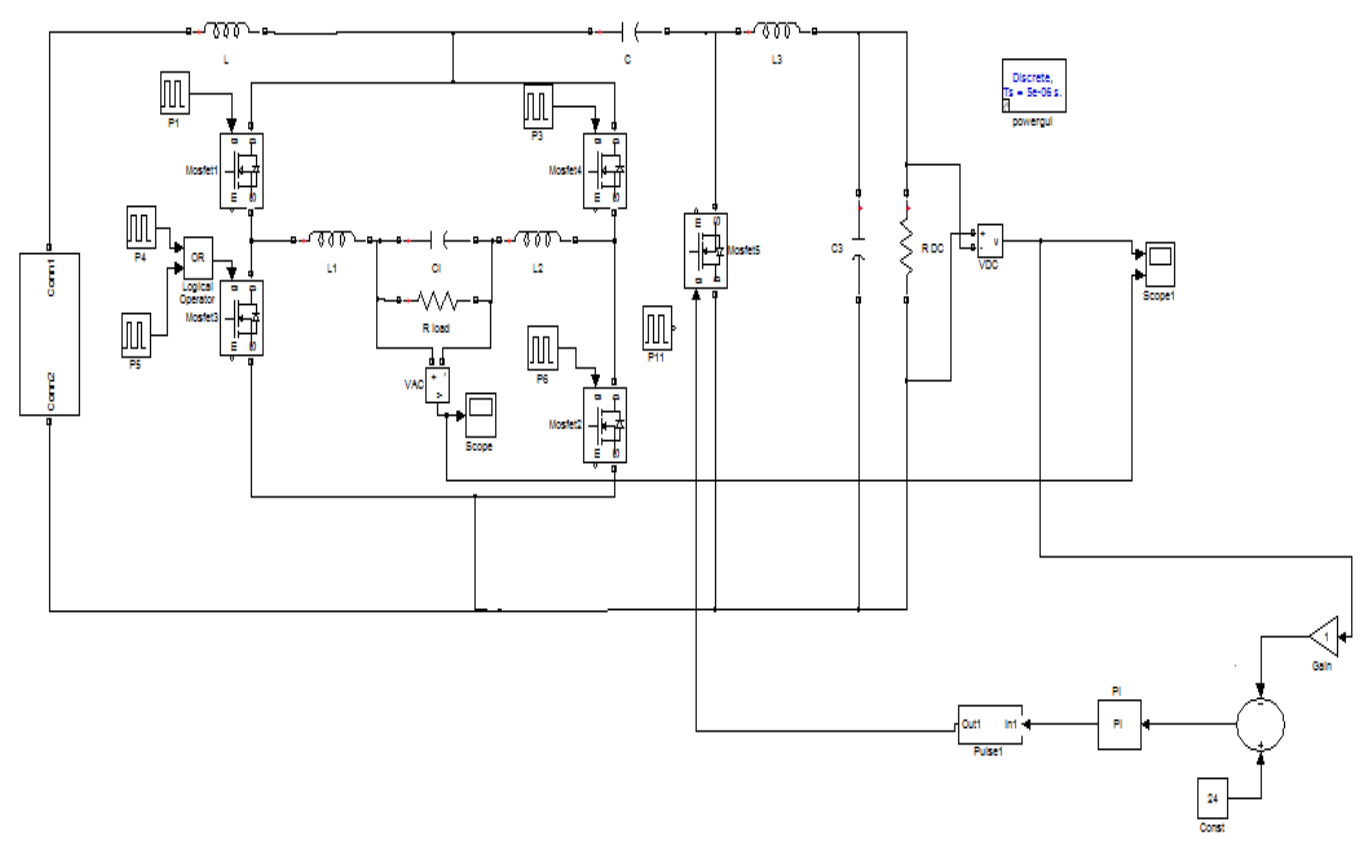

Fig. 4.1. Closed-loop HCCI system with PI controller

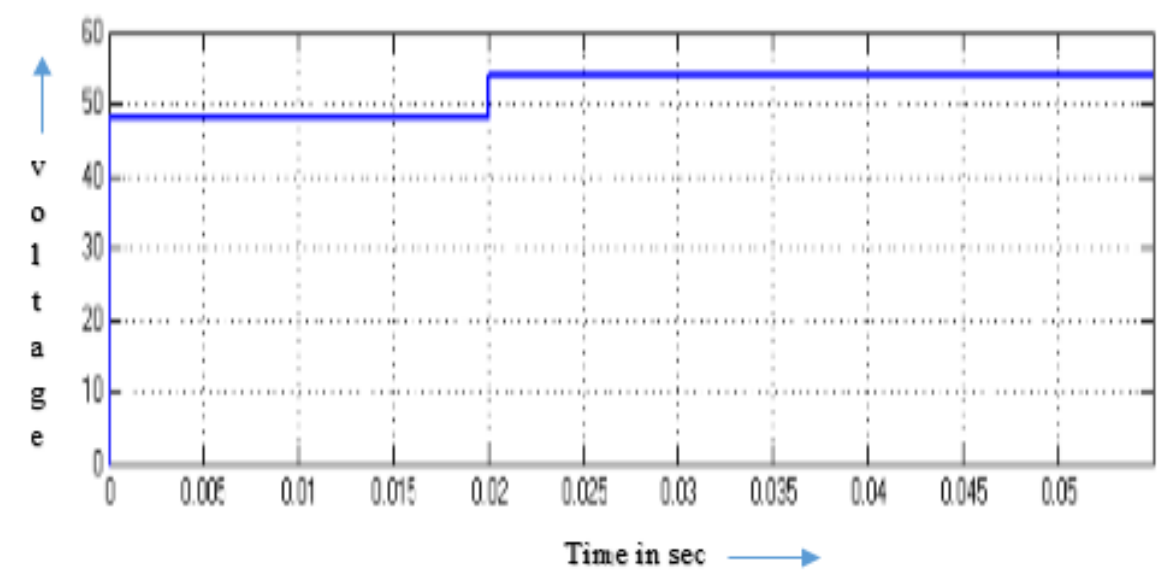

Fig. 4.2. Voltage fed to HCCI

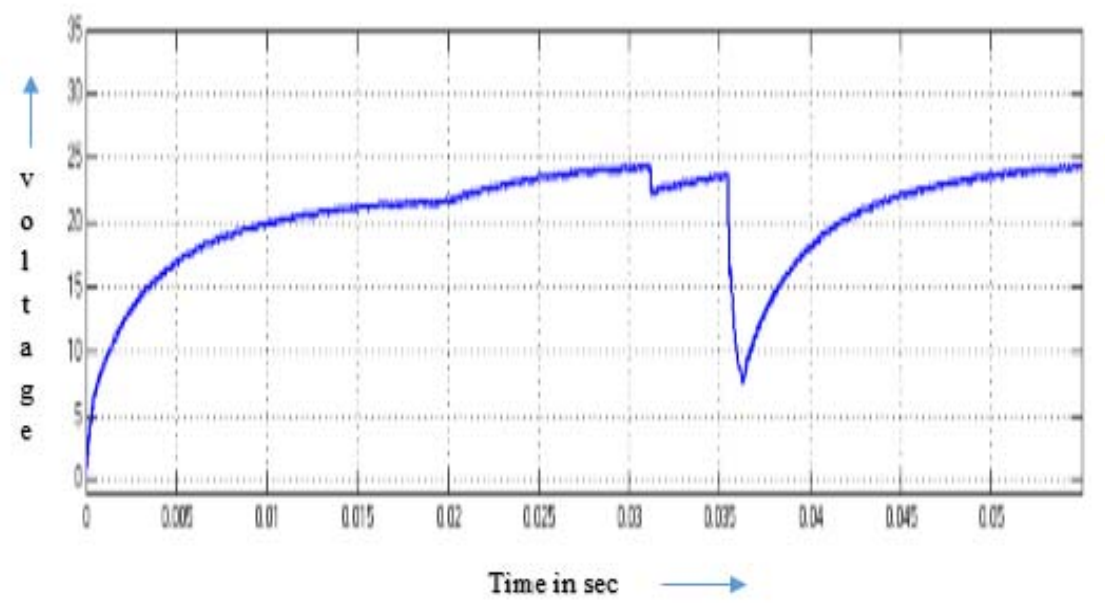

Fig. 4.3. Voltage response of HCCI 


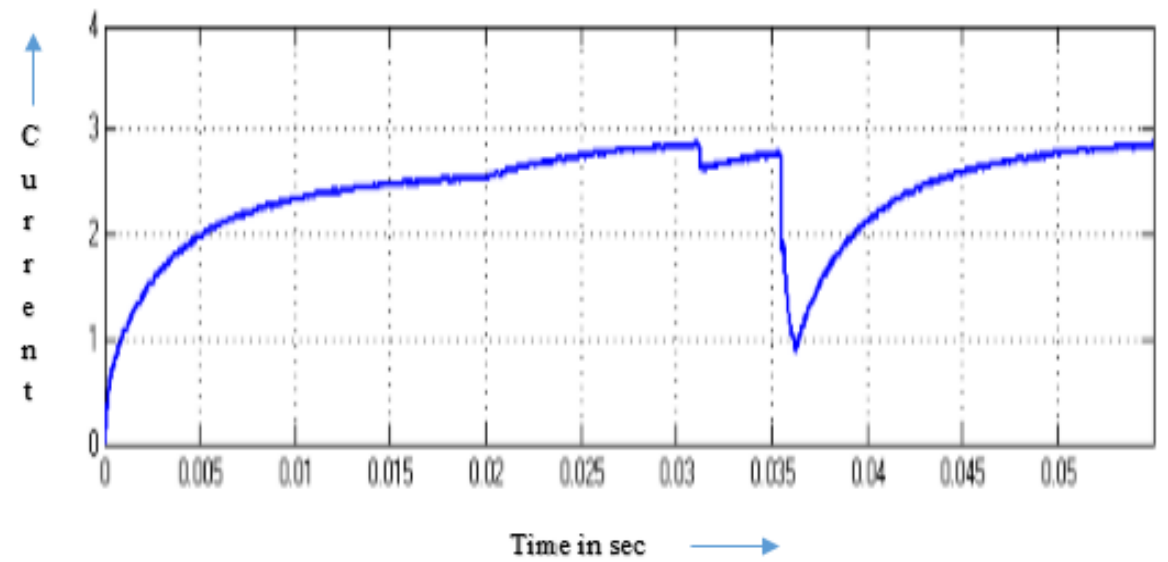

Fig. 4.4.Current response of HCCIS

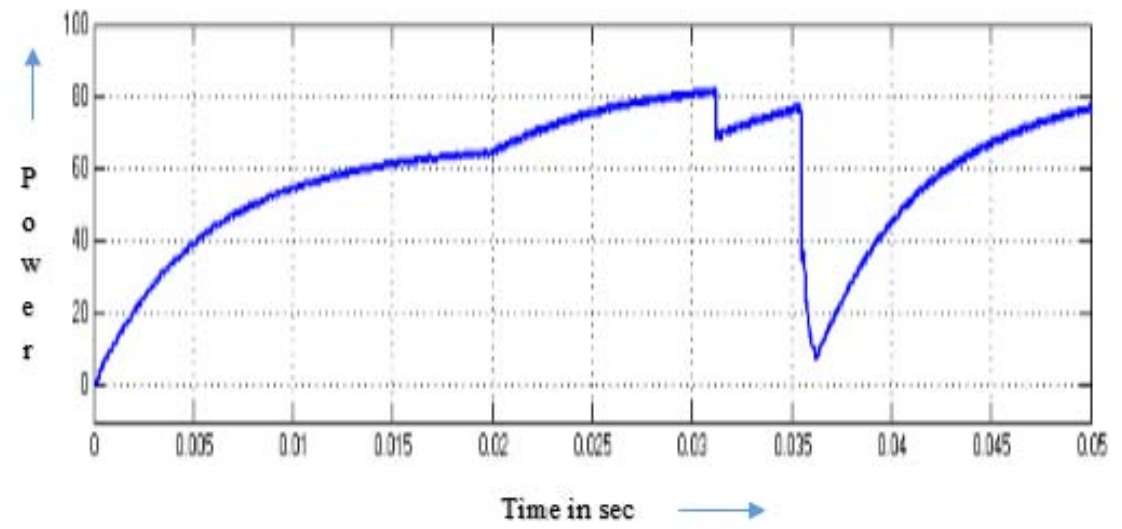

Fig. 4.5. Power response of HCCIS

Closed loop HCCI with PR controller is appeared in Fig. 5.1. The FOPID-controller in the previous circuit is substituted by PR controller. Summary of Time-Domain Parameters with PI \& PR Controllers for $V_{\text {ref }}=22 \mathrm{~V}$ are given in Table 1. Time-Domain-Parameters with PI \& PR Controllers for $\mathrm{V}_{\text {ref }}=24 \mathrm{~V}$ are given in Table 2. Summary of Time-Domain Parameters with PI \& PR Controllers for $\mathrm{V}_{\text {ref }}=26 \mathrm{~V}$ are given in Table 3.

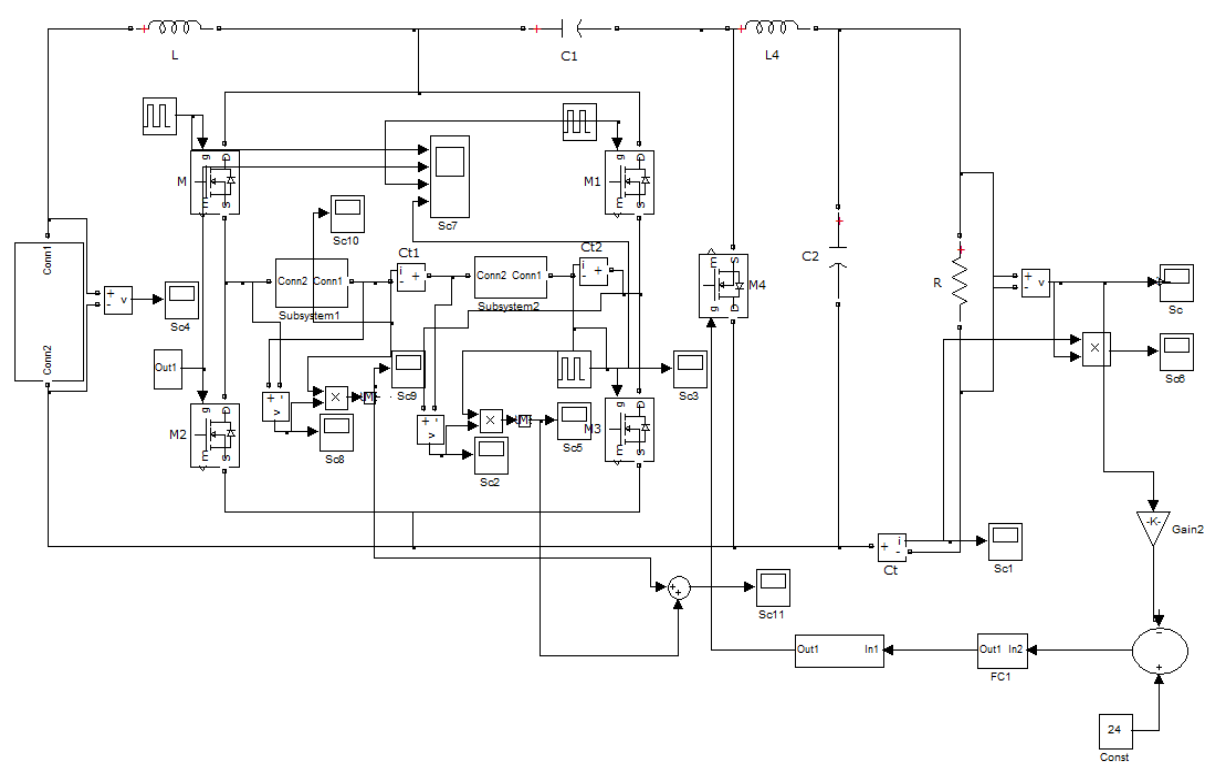

Fig. 5.1. Closed loop HCCI system with PR controller 
The fed voltage is appeared in Fig. 5.2 and its value is $55 \mathrm{~V}$. The current response of HCCI is shown in Fig. 5.3. The voltage and power response of HCCI system are shown in Fig. 5.4 and 5.5.

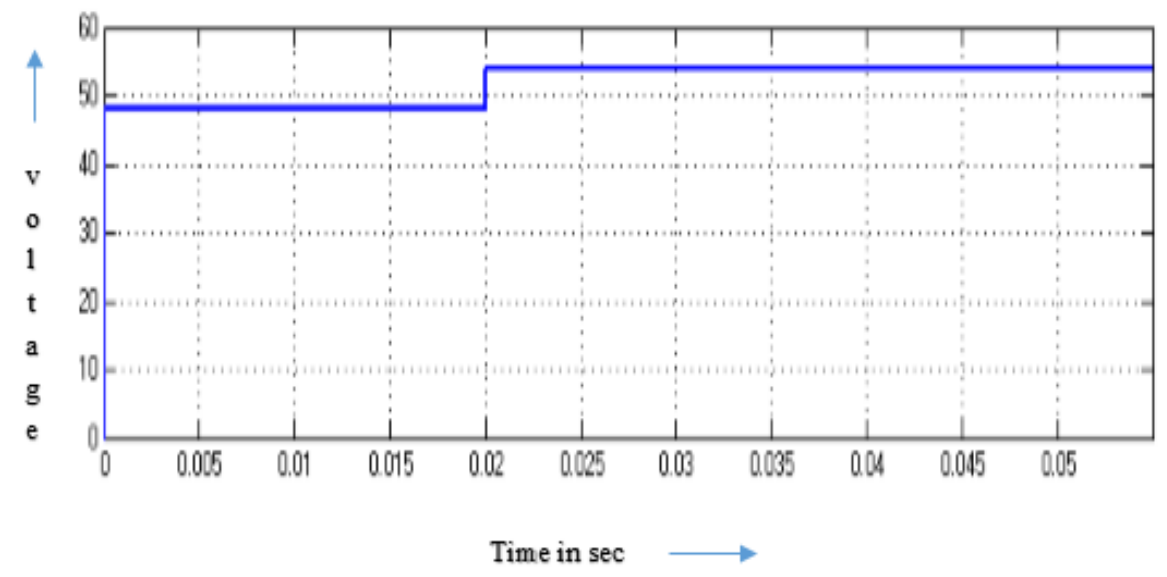

Fig. 5.2. Voltage fed to HCCIS

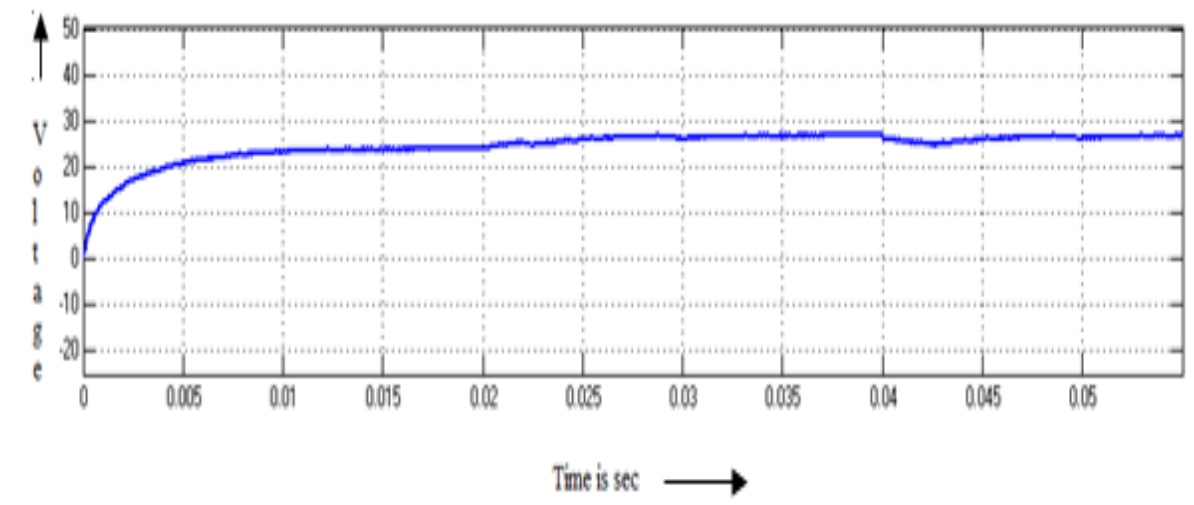

Fig. 5.3. Voltage response of HCCIS

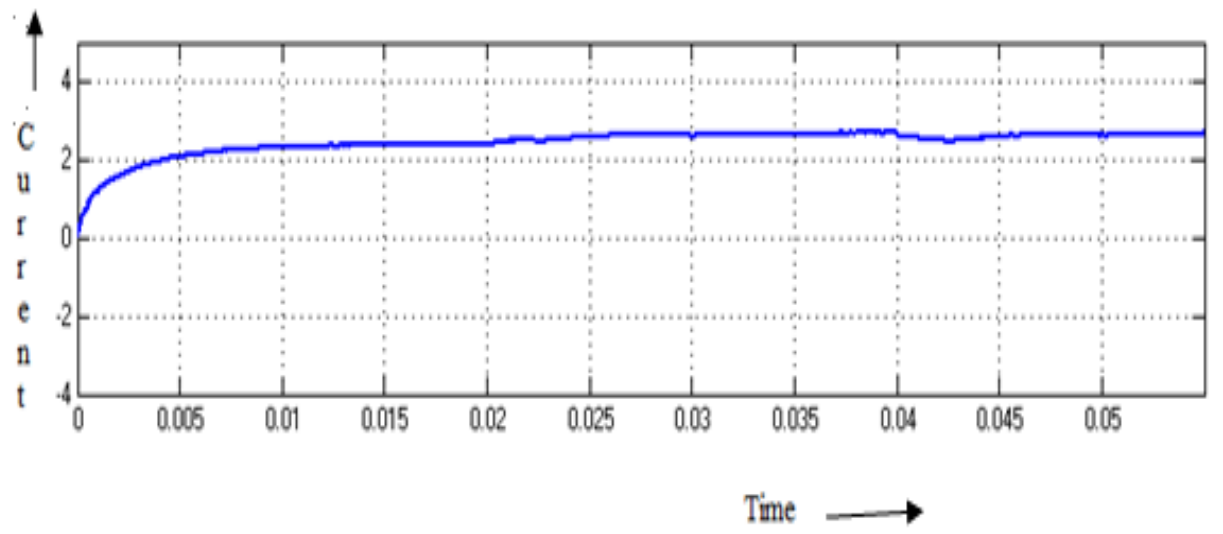

Fig. 5.4. Current response of HCCIS 


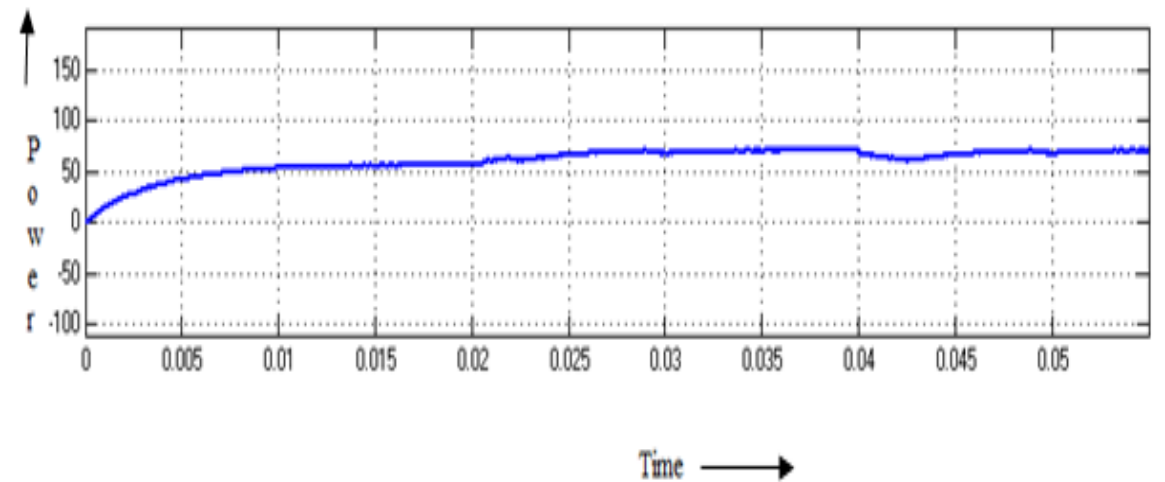

Fig. 5.5. Power response of HCCIS

TABLE 1 Instantaneous of Time-Domain Parameters with PI \& PR Controllers for Vref=22V

\begin{tabular}{|c|c|c|c|c|}
\hline $\begin{array}{c}\text { Type of } \\
\text { Controller }\end{array}$ & $\begin{array}{c}\text { Rise Time } \\
\text { (Sec) }\end{array}$ & $\begin{array}{c}\text { Peak Time } \\
\text { (Sec) }\end{array}$ & $\begin{array}{c}\text { Settling Time } \\
\text { (Sec) }\end{array}$ & $\begin{array}{c}\text { Steady State } \\
\text { Error (Volts) }\end{array}$ \\
\hline PI & 0.028 & 0.045 & 0.050 & 3.3 \\
\hline PR & 0.024 & 0.038 & 0.046 & 2.1 \\
\hline
\end{tabular}

TABLE 2 Summary of Time-Domain Parameters with PI \& PR Controllers for Vref $=24 \mathrm{~V}$

\begin{tabular}{|c|c|c|c|c|}
\hline $\begin{array}{c}\text { Type of } \\
\text { Controller }\end{array}$ & $\begin{array}{c}\text { Rise Time } \\
\text { (Sec) }\end{array}$ & $\begin{array}{c}\text { Peak Time } \\
\text { (Sec) }\end{array}$ & $\begin{array}{c}\text { Settling Time } \\
\text { (Sec) }\end{array}$ & $\begin{array}{c}\text { Steady State } \\
\text { Error (Volts) }\end{array}$ \\
\hline PI & 0.026 & 0.030 & 0.045 & 2.8 \\
\hline PR & 0.023 & 0.025 & 0.040 & 1.7 \\
\hline
\end{tabular}

TABLE 3 Summary of Time-Domain Parameters with PI \& PR Controllers for Vref $=26 \mathrm{~V}$

\begin{tabular}{|c|c|c|c|c|}
\hline $\begin{array}{c}\text { Type of } \\
\text { Controller }\end{array}$ & $\begin{array}{c}\text { Rise Time } \\
\text { (Sec) }\end{array}$ & $\begin{array}{c}\text { Peak Time } \\
\text { (Sec) }\end{array}$ & $\begin{array}{c}\text { Settling Time } \\
\text { (Sec) }\end{array}$ & $\begin{array}{c}\text { Steady State } \\
\text { Error (Volts) }\end{array}$ \\
\hline PI & 0.027 & 0.032 & 0.047 & 2.9 \\
\hline PR & 0.024 & 0.030 & 0.043 & 1.8 \\
\hline
\end{tabular}




\section{EXPERIMENTAL RESULTS}

The hardware for HCCI system is fabricated and tested. The hard ware consists of control board, inverter board and Cuk board. The total hardware circuit diagram of HCCI is appeared in Fig. 6.1.The snap shot for total hardware of HCCI is appeared in Fig. 6.2.

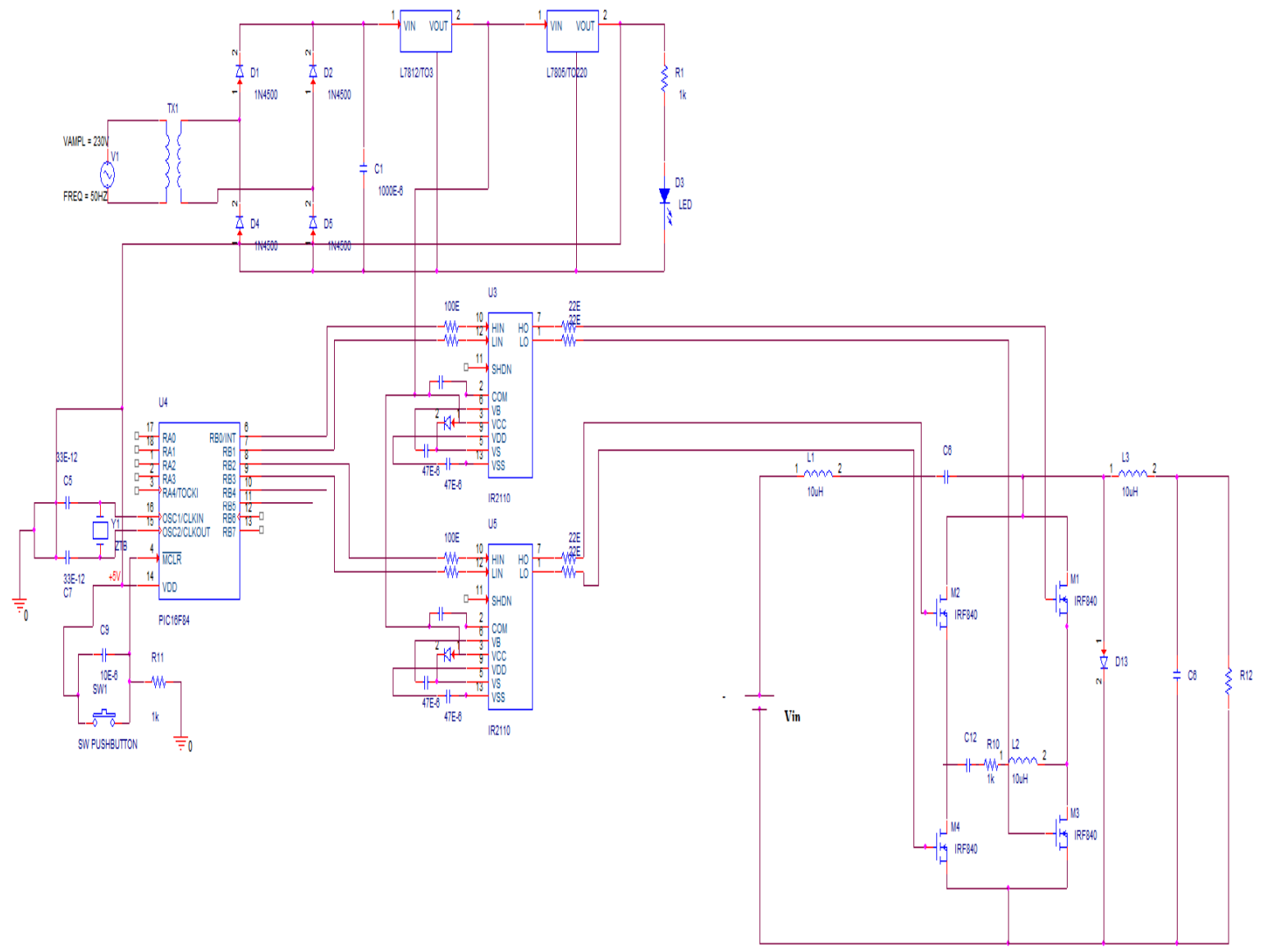

Fig. 6.1. Hardware circuit diagram

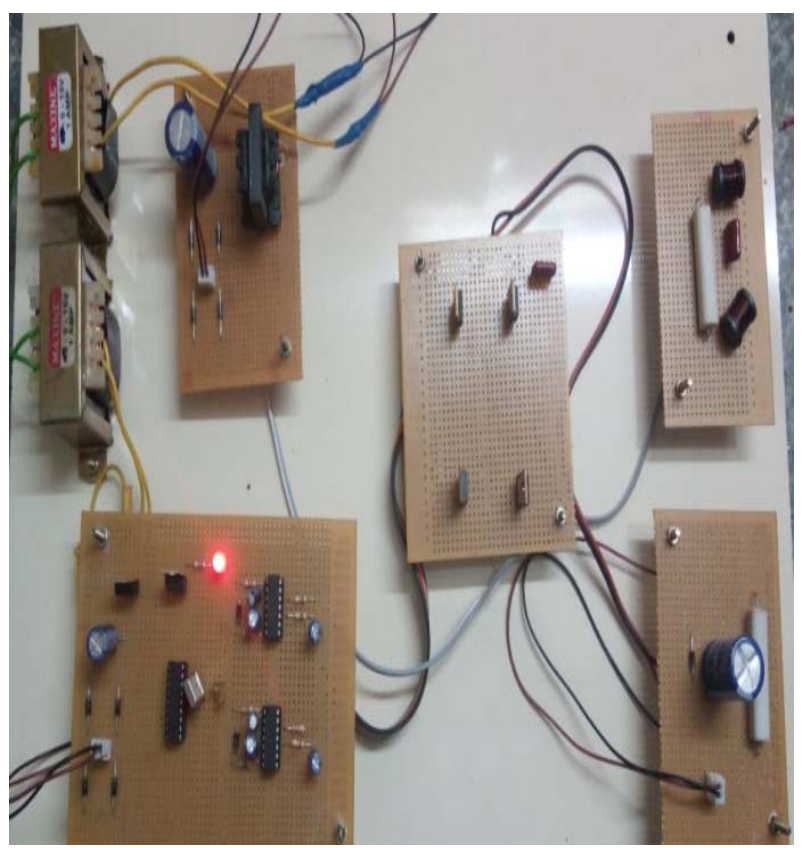

Fig. 6.2. Hardware snap shot 
Table 4 Comparison of simulation and hardware results

\begin{tabular}{|c|c|c|}
\hline Quantity & Simulation & Hardware \\
\hline Vin & $48 \mathrm{v}$ & $48 \mathrm{v}$ \\
\hline L1 & $50 \mu \mathrm{H}$ & $45 \mu \mathrm{H}$ \\
\hline L2 & $2.3 \mu \mathrm{H}$ & $4 \mu \mathrm{H}$ \\
\hline $\mathrm{C} 1$ & $2.8 \mu \mathrm{F}$ & $3 \mu \mathrm{F}$ \\
\hline Co & $2000 \mu \mathrm{F}$ & $2200 \mu \mathrm{F}$ \\
\hline Mosfet & IRF840 & IRF840 \\
\hline Diode & $1 \mathrm{n} 4007$ & $1 \mathrm{n} 4007$ \\
\hline Vco & $24 \mathrm{v}$ & $24 \mathrm{v}$ \\
\hline
\end{tabular}

The input voltage is shown in Fig. 6.3. The switching-pulses for switches M1 \& M2 are appeared in Fig. 6.4.The output-voltage of cuk-converter is appeared in Fig. 6.5.

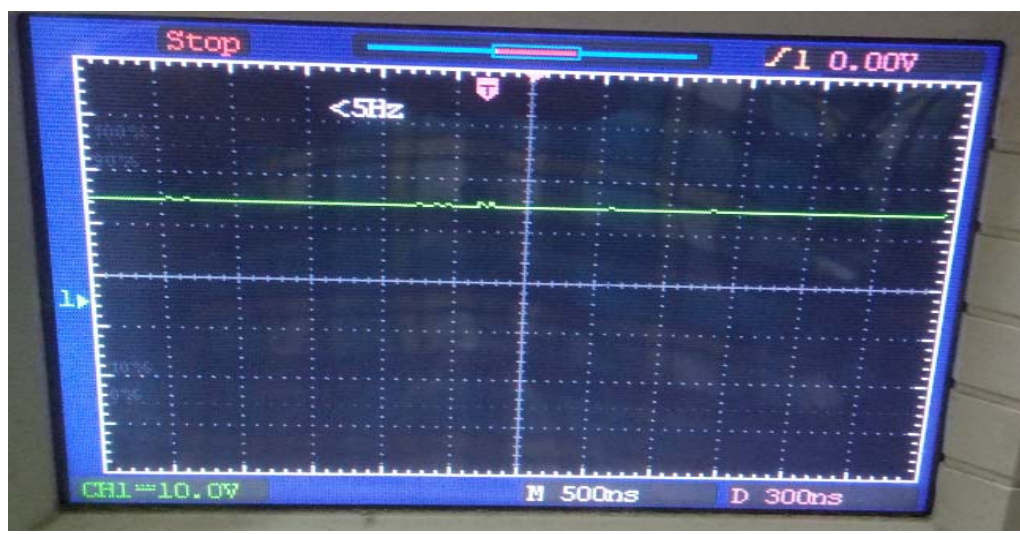

Fig. 6.3. Input-voltage

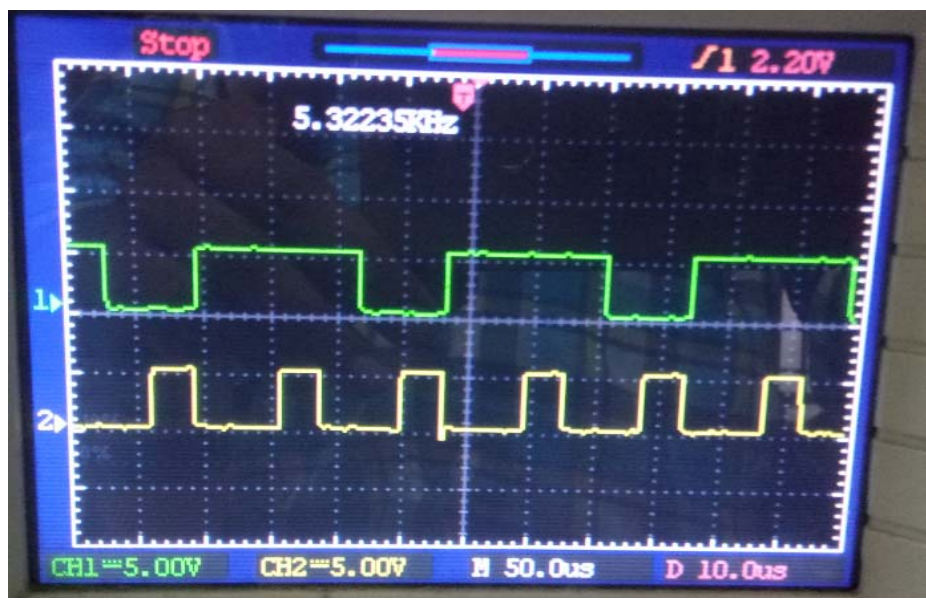

Fig. 6.4.Switching Pulses for M1 and M2

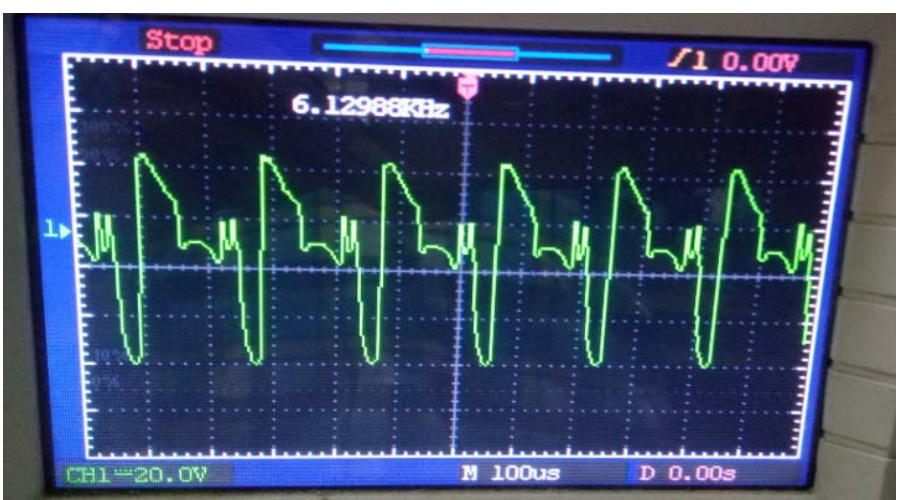

Fig. 6.5. Voltage response of inverter 


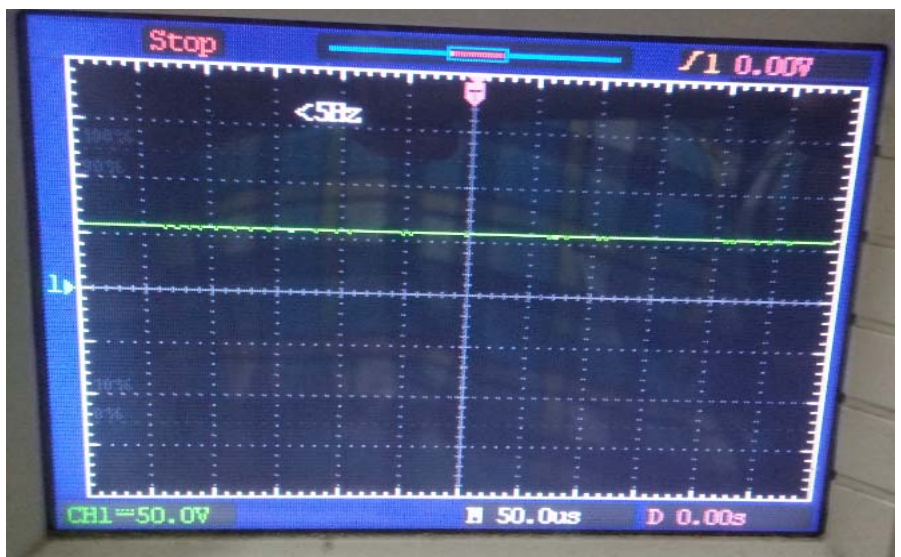

Fig. 6.6. Voltage response of cuk converter

\section{CONCLUSION}

Digital-simulation was performed for open-loop and closed-loop HCCI systems with PI and PIDcontrollers. These studies were executed utilizing the Simulink-based models for cuk converter - inverter system. The settling time is as low as $0.03 \mathrm{sec}$. The steady-state error in output-voltage is $1.5 \mathrm{~V}$. Therefore PR controlled system gave improved response as compared with PI controlled system. The hardware results are similar to simulation ones. The assistances of the recommended system are high-gain and enhanced response. The conduction-losses are amplified since first leg is for shoot through and inverter operation.

The extent of the present work is the examination of PI and PR controlled closed loop HCCI systems. The comparison between PI \& two loop PR based HCCI systems will be focused in future. Hardware at higher power level may be implemented at a later date.

\section{REFERENCES}

[1] Matysik, J.T, "A new method of integration control with instantaneous current monitoring for class D series-resonant converter,'IEEE Trans. Ind. Electron., October 2006, vol. 53, no. 5, pp.1564-1576.

[2] Acero, .J, Alonso, .L, Barragán, .L.A., "Modeling of planar spiral inductors between two multilayer media for induction heating applications," IEEE Transactions on Magnetics, Nov. 2006, vol. 42, no. 11, pp. 3719-3729.

[3] Kifune, .H, Hatanaka, .Y, Nakaoka, .M., "Cost effective phase shifted pulse modulation soft switching high frequency inverter for induction heating applications ," IEE Proceedings - Electric Power Applications, Jan. 2008, vol.151, no. 1, pp. 19-25.

[4] Arumugam, .S, Ramareddy, .S., "Experimental Studies on Class E Inverter based Induction Heater," International Journal of Computer Theory and Engineering, April 2011, Vol. 3, No. 2, ISSN: 1793-8201.

[5] Junghwan Moon, Seunghoon Jee, Jungjoon Kim,

[6] "Behaviors of Class-F and Class-F-1 Amplifiers," IEEE Transactions on Microwave Theory and Techniques, June 2012, vol. 60, no. 6, pp. 1937-1951.

[7] RavindranathAdda, Olive Ray, K. Mishra, and Avinash Joshi. ,'Synchronous-Reference-Frame-Based Control of Switched Boost Inverter for Standalone DC Nanogrid Applications," IEEE Transactions on Power Electronics, March 2013, VOL. 28, NO. 3, pp. $1219-1233$.

[8] Olive Ray, Santanu Mishra. , "Boost-Derived Hybrid Converter with Simultaneous DC and AC Outputs," IEEE Transactions on Industry Applications, March/April 2014, VOL. 50, NO. 2, pp. 1082 - 1093.

[9] Mury Thian, Ayman Barakat,Vincent Fusco., "High-Efficiency Harmonic-Peaking Class-EF Power Amplifiers With Enhanced Maximum Operating Frequency," IEEE Transactions on Microwave Theory and Techniques, Feb. 2015, vol. 63, no. 2, pp. 659-671.

[10] PadmanabhaSivakumar, G., Umapathy, .K., "Reduction of the THD in the Class F3 Amplifier System," International Journal of Scientific \& Engineering Research (IJSER), March-2016, Volume 7, Issue 3, ISSN 2229-5518.

\section{AUTHOR PROFILE}

S.Dinaka raj received the B.Tech degree in electrical and electronics engineering from SRM University, Chennai, India, in 2007 and the M.E. degree in electrical and electronics engineering from the Anna University, Chennai, India, in 2010, where he is currently working toward the Ph.D. degree in the Department of Electrical Engineering. His research interests include power converter, modelling and control, dc distribution systems, and digital control in power electronics.

G. Angeline Ezhilarasi received her bachelor's degree in electrical engineering from Madras University, master's degree in power systems engineering from Anna University, Chennai, India and Ph.D. degree in electrical engineering from IIT Madras, Chennai, India. She has worked as a Project Associate at IIT Madras, India for about 6 years and was involved in the content management and administration team of National Project on Technology Enhanced Learning. . She is currently a Professor with the VIT University Chennai, Chennai, India. Her research interests include Distributed Computing, Parallel Processing, power converter, modelling and control, de distribution systems. 